\title{
The Probable Trend of Interest Rates
}

\author{
By David Friday \\ Professor of Economies, University of Michigan
}

$\mathrm{T}$ IHE probable trend of interest rates in the United States for the next two years will depend upon the forces which operate on the capital market during that period. Obvious as this sentence may seem, it nevertheless implies a deal of wisdom about the causes which underlie the movements of interest rates. It is wisdom, too, which it took the world a number of centuries to acquire, and which is even yet far from being a part of our common stock of knowledge. For this implies that interest is a price, and that, like all prices, it is the product of the workings of a market.

Interest Is a Price Which Must

Be Forecast by a Studuy of CapItal Supply and Demand

Since it is a market price, the forces which determine it must manifest themselves upon that market, either in the form of changes in supply or in the form of alterations in demand. Nothing can influence the rate of interest, any more than other prices, unless it operates to change either the supply or the demand. This implication of the first sentence may be considered as elemental, and may be accepted without argument or proof. So much has been established since the day when John Locke, at the close of the 17th century, wrote his Considerations of the Consequences of the Lowering of Interest and Raising the Value of Money.

In order to forecast the probable trend of interest rates, then, we must forecast the probable course of the demand for capital and the probable supply of capital at different rates of interest.

\section{The Source of Capital}

The supply of capital during any given period of time consists of the excess of production over consumption. If, within the current year, the people of the United States produce fifty billion dollars' worth of goods and services and consume forty-two billion dollars of them in ordinary family and personal living expenses, the national supply of capital for the year will amount to eight billion dollars. This is the amount which will be available to meet the demands of those who desire to borrow capital. The supply of capital is created by people who do not consume the total amount of their product, but who put a portion of it at the disposal of the borrower. They wait until the future before they enjoy, through actual consumption, the fruit of their efforts.

\section{The Nature of Capital and Capital Demand}

The borrowers, who make the demand for capital, desire it for use in production or for consumption and enjoyment. They wish to buy and have for immediate use the goods which the suppliers of the capital have produced. These goods are of two sorts. They may consist of produced goods devoted to further production, like plant and machinery, raw materials and partly finished goods, and other working capital which is to be employed in the business activities in which the borrower is en gaged. Or 
they may consist of things which are not used in production, but which are employed for personal enjoyment, such as houses, automobiles and furniture. These durable goods used for consumption, together with those used in productive activities, constitute the national capital. Their distinguishing characteristic is that they are durable goods, and that their creation and use involve the expenditure of productive effort by people who are willing to wait before they reap the full fruition of their work. Money is simply one form of these durable goods, and, like other forms of capital wealth, is a useful instrument. Its particular function is to act as a medium of exchange in carrying on the trading activities incident to our modern industrial process.

\section{An Abundant Supply of Money in Itself Does Not Make Low INTEREST RATES}

It should be noted in passing, that an abundant supply of money does not in itself make interest lower. What the borrower really desires is not money, but the things which money will buy. The important thing that the lender does when he hands him his money is to promise that he will wait for repayment, postponing, in the meantime, his own demand for goods upon the market. This distinction between money and capital is one which must be firmly held in mind if utter confusion is to be avoided in explaining fluctuations in the interest rate.

It is true that while people desire goods ultimately, they borrow not goods, but money; and it would seem, therefore, that more money would mean a larger supply of the thing which is immediately borrowed. And so it is. Momentarily, such an increase does reduce the rate of interest, especially for bank loans. When in 1915 and 1916
Europe sent America almost one billion dollars in gold, this was added to the bank reserves of the country. The increased supply of money and the bank credit which it served to support, kept the bank rate low for a period of two years, despite the fact that the demand for loans increased greatly in this period. As will be seen later, the increase in money during this period was supplemented by an actual increase in saving. But without question the great increase in the supply of money and bank credit had an immediate effect upon the rate of interest.

But no one who has watched the increasing volume of money and credit and the rate of interest since 1917, should labor any longer under the delusion that an increase in the quantity of money brings about a lower rate of interest. The world has never had half the quantity of money and credit before that it has now; and it has not for half a decade seen such high interest rates. The reason why an increase in the quantity of money cannot long keep interest rates low is that it is always accompanied by an increase in the level of prices. Since the borrowers desire not money but goods, they must borrow a larger quantity of money funds than before in order to buy the same amount of capital goods. As soon, therefore, as the increase in money has effected an increase in price, the demand for money funds increases as rapidly as the supply, and interest rates are fully as high as before. All of this has been clear to economists since the days of David Hume. It is an increase in willingness to wait, an increase in savings, not an increase in money, which reduces the rate of interest for long-time loans. The supply of capital consists of savings, and savings consist of the excess of production over consumption. 


\section{Fundamental Propositions Respect- ING INTERest Rates}

In discussing the possible trend of interest rates we shall accept the following propositions as fundamental. Interest is the price paid for the use of capital. Capital is created by producing more than one consumes. The essence of the service which the lender performs to the borrower is in the waiting which he undergoes when he places his purchasing power at the disposal of another. From the standpoint of the nation as a whole, the essence of capital creation consists in the application of labor and material to the production of durable goods, like plant, machinery, railroads and public utilities, houses and automobiles, which give off their uses gradually over a period of time, and which therefore require waiting between the production of the goods and the enjoyment of the services which they render. Since interest is a price, it is determined by the forces of supply and demand, and cannot be greatly affected by legal enactment. Money is only one form of capital, and the supply of capital does not depend upon the supply of money, but upon the nation's saving. An increase in the quantity of money will not for any considerable length of time reduce the rate of interest.

\section{Demand Factors Have Had Major Effect on Interest Rates}

By far the most important fluctuations in the fundamental factors which control interest rates occur on the side of demand. Whenever the demand for capital for the construction of plant, machinery, power plants, transportation facilities, automobiles, furniture and musical instruments, has been active, the rate of interest has risen in consequence. This was the situation during the ten years preceding the out- break of the European war. During that time the rate of interest on highgrade bonds rose from $31 / 2$ per cent to almost 5 per cent. This was for seasoned bonds which were already in the hands of permanent investors. The rate paid for new capital obtained from underwriters rose even more. There is no doubt that during this very period the supply of capital grew much more rapidly than it ever had before. The savings deposits of banks, the annual savings through building and loan associations and through life insurance premiums, the reinvestment of profits by corporations, the savings of the farmers, all show increases in the supply of capital which far exceeded anything which this country had seen previous to $\mathbf{1 9 0 0 .}$

But the demand for capital went on at a rate which outran even this increase in supply. During the decade and a half which ended in 1914 the United States became a great manufacturing nation. Cities in the middle west, like Flint, Michigan, and Akron, Ohio, had been "buckwheat towns" in 1899 ; in 1913 , they were manufacturing centers of importance. Pleasant leisurely cities, like Detroit, grew in a short space of time into manufacturing cities of first rank. The whole public utility field multiplied its investment by about five during this period. What this signifies for the demand for capital will appear in the facts concerning such a corporation as the Bell telephone system. Between 1876 and 1900 this system had invested roughly $\$ 300,000,000$ in plant and equipment; during the next thirteen years they invested, in addition, twice that amount. The amount of capital invested in electric light and power companies, in street railways, in improvement to the roadway and equipment of steam railroads, far outran any rate of investment which had ever occurred before. 
In addition to this large growth of American industries, both public and private, there was an increase in expenditure on better buildings, upon pavements and sidewalks, and above all things else, upon a very much improved and more expensive type of house. No explanation of the increase in the rate of interest which occurred just before the outbreak of the European war is possible without a recognition of the revolution which had occurred during this period in residential construction.

All of this increase in the demand for capital was occasioned in large measure by the swing-out of invention and technical improvements following the advent of electricity and the general application of science to the problems of industry. One invention of the period deserves particular mention because of its importance in the demand for capital. The automobile was developed and came into popular use during this period. This not only called for capital with which to erect factories, but every motor car was itself a source of demand for capital, because it was a durable good whose use involved waiting. By 1914 the people of the United States had accumulated a stock of almost two million automobiles. These had created a demand for capital which had been non-existent previous to this decade.

In the capital markets of the world a similar development in industry created a like increase in the demand for capital, and drove up interest rates. But the outside world had a further source of demand which had been absent during the period from 1871 to 1900 : those years had been years of peace. War is always a source of greatly increased demand for capital. A war of first magnitude, such as that of 1914 to 1918 , absorbs practically the entire excess of production over consumption while it is going on. In the case of the European nations it went even farther than this and absorbed not only the new supply of capital created during the period of hostilities, but encroached upon the previously created capital as well.

The period from 1900 to 1914 was not free from war as had been the thirty years previous. Just at the close of that thirty years, in 1898, came the Spanish-American war. It was not of sufficient duration or extent to strain the national supply of capital. In 1900 came the Boer war, which cost England more than one billion dollars, to say nothing of the cost to the Boers. In 1904 occurred the Russo-Japanese war; this absorbed the entire capital of both parties to the conflict, and, in addition, called upon the European markets for more than one billion dollars' worth of capital. Only a few years elapsed before the Balkan wars broke out. The demand for capital for military purposes was active, therefore, throughout the decade which preceded the European war. All these forces working to increase the demand for capital had raised the rate of interest by almost one-half between 1904 and 1914.

\section{The Contrast in Capital Demand \\ During the Periods 1890-1900 AND 1900-1914}

This period of rising rates of interest may be set in contrast with the period which had preceded it-a period in which interest rates fell even in the face of a fairly small supply of capital. In 1898 the President of the New York State Bankers' Association, an experienced practical banker of unusual sense and insight, said in his annual address:

The days of six per cent interest are gone, only to return at troubled intervals when normal conditions are disturbed. The choicest investments yield less than 3 per 
cent. Some railroad bonds commanding $3 \frac{1}{2}$ per cent command a premium. Rentals are proportionately reduced, and these conditions have come to stay. The growing wealth of this country is enormous, and as a permanent condition we must recognize four per cent as a good return for investment.

This statement shows the general situation which prevailed at the time. Interest rates were low, and wise, practical men thought they would not again rise. What this practical banker did not foresee was the great increase in industrial enterprise and activity, accompanied by largely increased profits and an enormous growth in the demand for capital with which men could seek those profits. Nor could he foresee that the world was to enter upon two decades of war and rumors of war, ending in the most destructive orgy which the world had yet witnessed.

During the nineties, the country had experienced a severe depression, which had diminished production, cut down profits, brought financial ruin to individuals and businesses, and discouraged enterprise generally. The profits of the national banks of the United States as a whole were $61 / 2$ per cent during the ten years 1890-1899; in the decade $1900-1909$, they were 9.88 per cent. These profits are simply a reflection of the profits which were being made in industry generally in the years after 1900. In such a situation the demand for capital was small, even at low rates of interest. After 1899, business had revived, production was thriving, profits were high, the spirit of business enterprise wasexuberant, and men demanded large quantities of capital at high rates of interest. When profits are 10 per cent men will bid much higher and more actively than when they are 61/2 per cent. The difference between the rates of interest which prevailed in the two decades is to be explained by this difference in the two situations, and by the manner in which that difference affected the demand for capital.

\section{The Future Trend of Interest \\ Rates Will Be Affected BY the Degree of Business Activity}

Will the situation for the future be more like that of the nineties, when the demand for capital was low and when interest rates fell in consequence, or will it resemble the decade which followed 1903? Will business men be optimistic? Will their profits be large, and will they be bidding constantly and anxiously for capital at a high rate? If we are entering a period when the business of the country will be characterized by conservatism, by a tendency to expend only such an amount of capital as is necessary to put existing plants in order, rather than to build new plants and promote new enterprises, and if investors are inclined to demand bonds and other safe investments rather than stocks and speculative securities, then the rate of interest is sure to fall.

\section{Bank Rates Sure to Fall}

What then is the outlook for the immediate future? To the extent that the rate of interest means the bank rate for short-time loans, it has fallen even now and seems due to fall further in the near future. Here the demand is for money, and the banker's lending power is determined primarily by the state of banking reserves. One year ago the ratio of the reserves of the Federal Reserve Banks to the deposit and Federal Reserve note liabilities was 42.8 per cent. In such a situation the additional lending power of the member banks was rapidly approaching extinction. On June 29, 1921 the reserve ratio stood at 60.8 . It bids fair to rise more in the immediate 
future. In part, this increase in reserve ratio has been brought about by a decrease in loans of member banks followed by a decrease in deposits, which in turn led to reduced reserve requirements with the Federal Reserve Banks, and to a decrease of approximately twenty per cent in the volume of Federal Reserve notes outstanding since the high point of last December. In part, the improvement in the ratio is due to an increase of five hundred million dollars in the gold reserve of the Federal Reserve banks.

With a reserve ratio of more than 60 per cent, and with a fall in the demand for loans occasioned by the decline in business activity and falling prices, the interest on bank loans could not long remain at its high level. The call rate has fallen materially, for the reserves of the Federal Reserve Banks of New York and Boston are far above those of the other ten banks. It is improbable too, that the Federal Reserve Board will keep rediscount rates at their former level in view of the growing reserve ratio. Bank rates, then, will surely fall.

Capital Demand for New Enterprises Will Not Be Heavy DurING the Next Two Years

In an analysis of the more fundamental question of rates on long-time louns, like mortgages and new bond issues of substantial concerns, municipal bonds, and the yield of stable bonds quoted on the exchanges, the situation is more complex. But if one keeps in mind the fundamental fact that the primary factor which makes a large demand for capital is the desire of the people to get capital for the construction of durable permanent wealth, for production and consumption, he will be able to forecast the situation in its main outlines at least. The demand for capital to be used in the promotion of new business enterprises will be comparatively slight during the next two years.

Not a few people believe that the demand for capital for the promotion and extension of industrial plants will be the source of a large demand for all our available capital. They argue that the development of American enterprises has been suspended or checked since the outbreak of the war, and that the resumption of expansion is inevitable. It sounds rather queer to hear almost in the same breath that the expansion of industrial plants has been checked, and that productive capacity has far outrun domestic consumption. If we can produce twentyfive per cent more than the home consumer will purchase, and if industrial profits are lagging in consequence, there can be no great need for immediate expansion. There is much reason to believe that our expansion of industrial plants from July, 1915, to July, 1918, was at a quite unprecedented rate.

We must distinguish here, too, between the desire for capital and the effective demand for capital. The hungry boy outside the candy shop has an enormous desire for the shopkeeper's product, but his wants do not constitute effective demand. So there will be many promoters of business ventures who desire the capital of the investing public, who will not be able to present an argument attractive enough to convert their want into an effective demand. The investor simply will not listen to them at all, and that source of demand which has been so large for the past few years will be much reduced for the period immediately confronting us.

Capital for Building Will Be Available When the Building Revival Comes

The largest demand that is now in prospect for capital is that which arises 
out of building, especially residential construction, and out of the need for public improvements, including improvements of our public utilities and railroad system. If the building boom were actively under way at this moment the acceleration of that demand would offset the decline in other directions in considerable measure. But thus far, the public has not had sufficient confidence in the future price of houses to make it willing to engage in construction on any large scale at present building costs. Before the building trade revives in sufficient degree to make a large draft upon the supply of capital, the volume of that supply will be quite sufficient to meet the demand at a rate materially lower than the one which now prevails.

Absorption of State and Municipal Bonds Not a Serious Matter

True, the demand for capital from states and municipalities for the prosecution of projects like road-building and for the payment of soldiers' bonuses is large. But it will probably not be in excess of one billion dollars per year and much of it will remain capital instead of being spent for consumption goods. The soldier who draws a bonus of $\$ 300$ and pays a loan at a bank, or makes a payment against the mortgage on his home, or deposits it in a bank as a savings account, or buys a safe bond already on the market, does not make any demand for new capital. In a nation which is saving, as we probably are even this year, between six and eight billion dollars per annum, the absorption of a billion dollars of state and municipal bonds is not a serious matter.

It is true there is a large volume of refunding of railroad, industrial, and government bonds which must be carried through within the next few years. But refunding does not absorb new capital except to the extent that the bondholder spends his money when he is paid off. Most bondholders are not that sort of people.

The Foreign Demand for Capital Will Probably Not Reach a Billion a Year

There remains the foreign demand. We hear much these days of the tremendous waste of capital in Europe during the war, and the billions upon billions needed to repair that waste. It is true that Europe needs capital and wants capital for the rehabilitation of her industries. The United States has sent it to her in abundant measure during the last five years. Even since the signing of the Armistice we have been sending her more than two billion dollars per year. And she will desire much capital for the future. But this is again a case of the hungry boy outside the candy shop. Europe's wants for capital will not become effective demand to any such extent as many people believe. It is doubtful whether during the next five years we will send her as much as one billion dollars per year. She would gladly take more than this at good interest rates, but American investors will not be willing to accept the security which she can offer in return for any great amount of capital. The experience of our exporters of capital to Europe thus far is not one to make us optimistic on this point.

\section{Exaggeration of NeEd of Exporting Capital}

The necessity of exporting capital to keep foreign trade going and thus keep the wheels of American industry turning, seems to me to be much exaggerated. Another statement from the address of the President of the New York Bankers' Association in 1898 shows how easy it is to overestimate the 
necessity for export of capital. $\mathrm{He}$ puts his conception of the relation of American industry to foreign trade in 1898 thus:

Our capacity to produce far exceeds our capacity to consume. The home market can no longer keep furnaces in blast or looms in action. That capital may earn its increment and labor be employed enterprise must contend in the markets of the world for the sale of our surplus product. ... Our money and our credit must follow and aid our merchandise in seeking customers in those countries that consume more than they produce.

This statement was made after business had been stagnant in this country for four years. During the fifteen years which followed, American industry produced an unprecedented volume of goods, and got them all consumed without exporting capital to Europe. The average income per man, woman, and child in this country is only about $\$ 500$ per annum. Even a college professor's family can consume more than that!

\section{The Outlook Is for Reduced Capi- tal Demand and Supply}

The net export of American capital, after allowing for gold movements, has been reduced 40 per cent since a year ago. The corporate security issues for the first five months of 1921, which require new capital rather than refunding, are likewise 40 per cent below those of 1920. Taking the situation as a whole the outlook is for a demand, both for bank loans and for long-time investment capital, much below that which we have witnessed during the last five years.

On the side of supply there will also be a reduction. The very fact that the supply of capital is determined by the excess of production over consumption makes this inevitable. When praduction decreases, savings must fall unless consumption is cut down by a like amount. In periods of industrial depression the fall in productive output is always the most striking feature of the situation. Consumption falls somewhat, but to a smaller degree than production, so that there is some decline in savings, especially in the earlier stages of business depression when the decline in production is acute. As industry works out of this first stage and production revives in some degree, consumption still remains low. As a result of these forces the supply of capital falls less than does the demand. The result is a decline in the rate of interest.

Not only does the supply decline less than the demand, but in times of depression the available supply is shifted away from the highly risky and speculative market to the market for safe and seasoned securities where the rate is habitually lower. The interest rate to borrowers who have high-grade security to offer falls decidedly, therefore, in such times.

It is a fact worth noting in this connection, that the Liberty bonds sold upon the New York Stock Exchange declined in volume from one billion three hundred million dollars in the first five months of 1920 to seven hundred and thirty million in the corresponding months of 1921. Evidently people are already more anxious to hold the high-grade securities which they have, than to sell them and invest the proceeds in more speculative ventures. As soon as these securities begin to rise decidedly in the market, this tendency will be accelerated.

\section{The Trend of Interest Rates Will Be Downward}

Upon the whale, it is most likely that the supply of capital for well-seasoned securities will equal the demand at a rate of interest decidedly lower than 
that which now prevails. We will not return for a long time to the low interest rates of twenty years ago, but it seems entirely likely that we will work well down to the level of 1913 . Liberty bonds, unless some unforeseen event arises, should be at par within three years, and all high-grade investment securities of long maturities should rise accordingly.
It is always difficult to forecast for any considerable period in the future the resultant of such complex forces as those which underliethe rate of interest. But the fundamental factors which operate upon the demand for capital and those which determine its supply after a period of business depression are such as will inevitably reduce the rate of interest.

\title{
Industrial Waste
}

\author{
By L. W. Wallace, M.E. \\ Executive Secretary of the Federated American Engineering Societies
}

$I^{1}$ January, 1921, Herbert Hoover, as president of the Federated American Engineering Societies, named seventeen engineers to make a study of waste in industry. The federation of engineering societies was new; Mr. Hoover was its first president. At the organizing meeting held in Washington in November, 1920, Mr. Hoover proposed the study and was authorized to make the investigation.

'There was peculiar fitness in the subject thus undertaken by the Federated American Engineering Societies, inasmuch as the object of the organization is to further public welfare whenever technical knowledge and engineering experience are involved, and to consider and act upon matters of common concern to the engineering and allied technical professions. The "assay of waste" undertaken by the Committee on Elimination of Waste in Industry was, as Mr. Hoover outlined it, to be a three months' investigation of a series of "samples" from which might be deduced general recommendations applicable to American industry as a whole.

The personnel of the committee consisted of eighteen carefully selected engineers. In selecting the members of the committee, care was taken to secure men of broad experience, clear concepts, and unbiased attitude towards industrial problems. Representatives of managerial, consultant, educational and editorial activities were chosen, with an eye also to their widely distributed and varied industrial contacts.

When the "assay" began, the committee itself selected with great care the engineers who conducted the field investigations. The engineering firm employed to investigate a given industry was chosen because it had a long and a favorable record in that particular type of industry. Thus was brought to bear upon the plans, findings and recommendations, the accumulated and composite knowledge and experience of some fifty or more engineers. In many phases of the work other specialists, such as economists, statisticians, employment managers and industrial physicians had an important part in collecting the material and in drawing up the conclusions. An earnest effort was made to obtain the advice and the accumulated information of every known agency or individual that could throw any light upon the subject in the time allowed. 